Article

\title{
Enhancing Perovskite Solar Cell Performance through Surface Engineering of Metal Oxide Electron-Transporting Layer
}

\author{
Gang Lu ${ }^{1,2}$, Xuhui Wang ${ }^{1}$, Juan Du ${ }^{1}$, Min Zhang ${ }^{1}$, Yali Gao ${ }^{1}$, Yanbo Liu ${ }^{1}$, Jing Ma ${ }^{3}$ and \\ Zhenhua Lin ${ }^{3, *}$ \\ 1 Qinghai Huanghe Upstream Hydropower Development Co. Ltd. Photovoltaic Industry Technology Branch, \\ Photovoltaic Technology Co., Ltd. of Huanghe Hydropower, Xining 810000, Qinghai, China; \\ eelugang@163.com (G.L.); wangxuhui@spic.com.cn (X.W.); dujuan@spic.com.cn (J.D.); \\ zhangmin@spic.com.cn (M.Z.); gaoyali@spic.com.cn (Y.G.); liuyanbo@spic.com.cn (Y.L.) \\ 2 Faculty of Automation and Information Engineering, Xi'an University of Technology, Xi'an 710048, China \\ 3 State Key Discipline Laboratory of Wide Band Gap Semiconductor Tecchnology, Shaanxi Joint Key \\ Laboratory of Graphene, School of Microelectronics, Xidian University, Xi'an 710071, China; \\ 18710628890@163.com \\ * Correspondence: zhlin@xidian.edu.cn
}

Received: 23 November 2019; Accepted: 20 December 2019; Published: 3 January 2020

\begin{abstract}
Perovskite solar cells have gained increasing interest in recent times owing to the rapidly enlarged device efficiency and tunable optoelectronic properties in various applications. In perovskite solar cells, interface engineering plays an important role in determining the final device efficiency and stability. In this study, we adopted $\mathrm{TiCl}_{4}$ treatment to reduce the surface roughness of the metal oxide layer and improve the perovskite film quality to obtain better device performance. After proper $\mathrm{TiCl}_{4}$ treatment, the efficiencies of $\mathrm{TiCl}_{4}-\mathrm{TiO}_{2}$ - and $\mathrm{TiCl}_{4}-\mathrm{ZnO}$-based devices were significantly enhanced up to $16.5 \%$ and $17.0 \%$, respectively, compared with those based on pristine $\mathrm{TiO}_{2}$ and $\mathrm{ZnO}(13.2 \%$ and $10.2 \%$, respectively).
\end{abstract}

Keywords: perovskite solar cells; $\mathrm{TiCl}_{4}$ treatment; electron-transporting layer; interface engineering

\section{Introduction}

Perovskite solar cells (PSCs) have attracted continuously increased interest owing to their unique properties and high performance [1-10]. In order to further enhance device efficiency and stability, some additional interface and compositional engineering approaches are necessary [11-18]. Some interface engineering approaches have previously been investigated to optimize energy level alignment and relieve charge accumulation [19-21]. Generally, for interface transport layers, a high-quality film with properties including sufficient charge extraction capability, good film conductivity, and proper energy level should be guaranteed [19,22]. Hence, various interface transporting layers have been studied. Among them, metal oxides (e.g., $\mathrm{ZnO}, \mathrm{SnO}_{2}$, and $\mathrm{TiO}_{2}$ ) have been widely investigated as electron-transporting layers (ETLs) in PSCs [23-37], particularly $\mathrm{TiO}_{2}$ ETL. The surface and electronic properties of $\mathrm{TiO}_{2}$ play important roles in determining the final device performance, including power conversion efficiency (PCE), hysteresis behavior, and stability [20,38,39]. In order to enhance device performance and reduce hysteresis behaviors encountered in $\mathrm{TiO}_{2}$-based devices, various techniques have been used to optimize the $\mathrm{TiO}_{2}$ surface or electronic properties. This includes the addition of fullerene molecules, amino acids, or C60-SAM, which are commonly applied to optimize the charge transfer process $[28,29,40,41]$. Besides this, $\mathrm{TiCl}_{4}$ soaking treatment has been investigated in dye-sensitized solar cells to enhance device performance [42]. $\mathrm{TiCl}_{4}$ treatment has also been 
applied in PSC devices to fill the voids at the $\mathrm{TiO}_{2} /$ perovskite layer interfaces and smooth the $\mathrm{TiO}_{2}$ surface $[39,43,44]$.

In this study, to investigate the mechanism of $\mathrm{TiCl}_{4}$ and the role it plays with $\mathrm{TiO}_{2}$ and phenyl-C61-butyric acid methyl ester (PCBM) in PSCs, we investigated the effects of $\mathrm{TiCl}_{4}$ treatment on the quality of perovskite thin film and the corresponding device performance. Results showed that, after $\mathrm{TiCl}_{4}$ treatment, the perovskite film quality was significantly enhanced; moreover, the charge transfer and extraction became more efficient. Finally, compared to pristine $\mathrm{TiO}_{2}$ - and $\mathrm{ZnO}$-based devices $\left(13.2 \%\right.$ and $10.2 \%$ ), the efficiencies of both $\mathrm{TiCl}_{4}-\mathrm{TiO}_{2}$ - and $\mathrm{TiCl}_{4}-\mathrm{ZnO}$-based devices were significantly improved up to $16.5 \%$ and $17.0 \%$, respectively, with simultaneously enhanced open-circuit voltage $\left(V_{\mathrm{oc}}\right)$, short-circuit current density $\left(J_{\mathrm{sc}}\right)$, and fill factor $(\mathrm{FF})$.

\section{Results and Discussion}

Surface morphologies of ETLs with and without $\mathrm{TiCl}_{4}$ treatment were investigated by tapping-mode atomic force microscopy (AFM) (Dimension Icon AFM, Bruker, Billerica, MA, USA). The surface roughness of the $\mathrm{TiO}_{2}$ surface decreased from 18.0 to $13.9 \mathrm{~nm}$ after $\mathrm{TiCl}_{4}$ treatment (Figure 1). After depositing the PCBM layer, the surface roughness was maintained without much change. This indicates that the surface roughness is mainly determined by $\mathrm{TiCl}_{4}$ treatments. These properties may affect perovskite crystallization and formation as well as the crystal size.
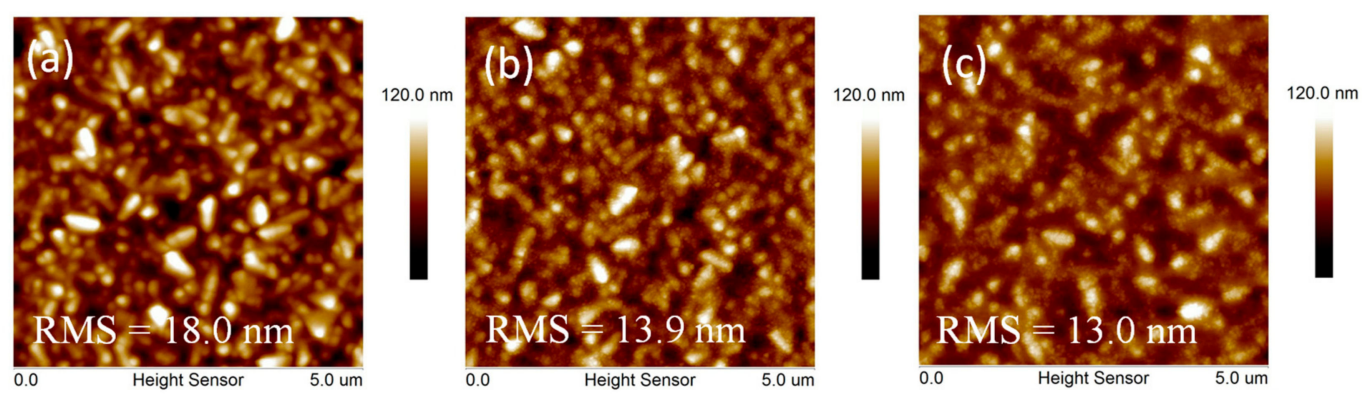

Figure 1. Atomic force microscopy (AFM) images of (a) pristine $\mathrm{TiO}_{2}$ electron-transporting layer (ETL), (b) with $\mathrm{TiCl}_{4}$ treatment, and (c) with $\mathrm{TiCl}_{4}$ and PCBM treatment.

The energy levels of $\mathrm{TiO}_{2} / \mathrm{PCBM}$ electron-transporting layers with and without $\mathrm{TiCl}_{4}$ treatment were investigated by ultraviolet photoelectron spectroscopy (UPS) (Escalab 250Xi, Thermo Scientific, Waltham, MA, USA). In Figure 2, it can be seen that the $\mathrm{TiO}_{2} / \mathrm{PCBM}$ work function decreased from 4.18 to $4.09 \mathrm{eV}$ after $\mathrm{TiCl}_{4}$ treatment. The decreased work function would result in better energy level alignment and more efficient electron transfer between the conduction band of perovskite and the Fermi level of ETL. Moreover, the potential difference between two electrode contacts, such as $\mathrm{TiO}_{2}$ and spiro-OMeTAD, was also enlarged due to the decreased work function, hence increasing the $V_{\text {oc }}$ of the device [33].

In order to illustrate the effect of $\mathrm{TiCl}_{4}$ treatment on the properties of perovskite thin film, the thin film morphologies of the perovskites upon ETLs with and without $\mathrm{TiCl}_{4}$ treatment were investigated. As shown in Figure 3, the perovskite crystal size was enhanced, indicating a favorable crystal growth process on the $\mathrm{TiCl}_{4}$-treated surface, which may have been caused by the low surface roughness value. The improved crystalline quality was also confirmed by the XRD patterns. As shown in Figure 4, strong diffraction intensity at around $14.6^{\circ}, 28.9^{\circ}$, and $32.3^{\circ}$ were observed and assigned to (110), (220), and (310) crystal planes of tetragonal perovskite phase, respectively. The diffraction pattern at 13.1 $1^{\circ}$ originated from $\mathrm{PbI}_{2}$ because of the excess $\mathrm{PbI}_{2}$ over $\mathrm{CH}_{3} \mathrm{NH}_{3} \mathrm{I}$. These results are consistent with those previously reported $[8,9]$. Moreover, the diffraction intensity of the perovskite thin films with additional $\mathrm{TiCl}_{4}$ treatment exhibited slight enhancement. This indicates that the thin film crystallinity was increased, resulting in more efficient charge transport and collection. 


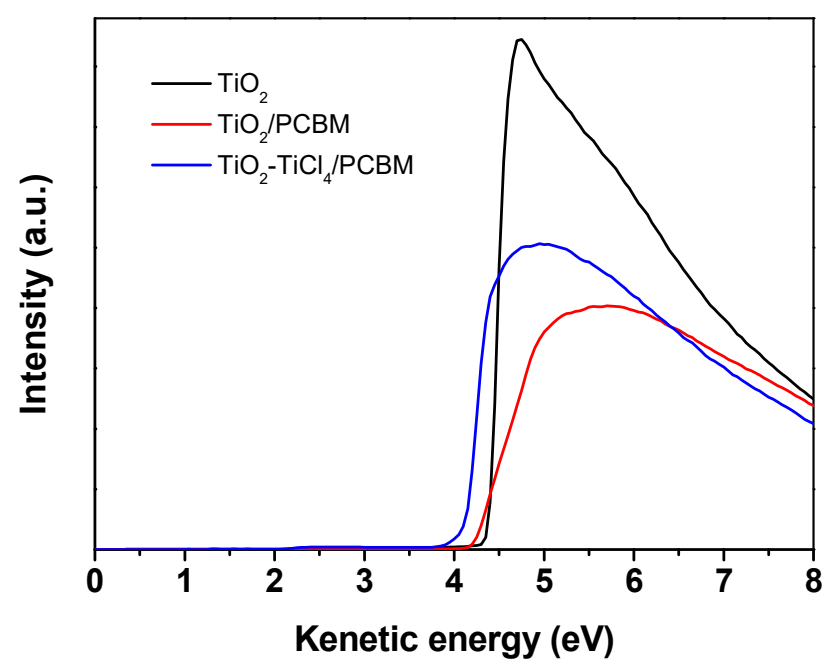

Figure 2. Ultraviolet photoelectron spectroscopy (UPS) spectra of ETL layers with and without $\mathrm{TiCl}_{4}$ treatment.

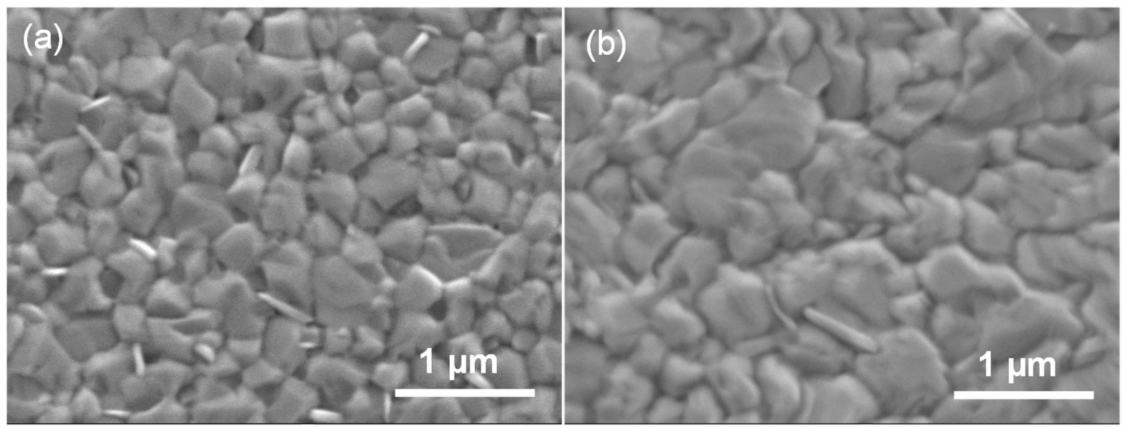

Figure 3. $\mathrm{SEM}$ images of perovskite films deposited on $\mathrm{TiO}_{2}$ (a) and $\mathrm{TiCl}_{4}$-treated $\mathrm{TiO}_{2}$ ETLs (b).

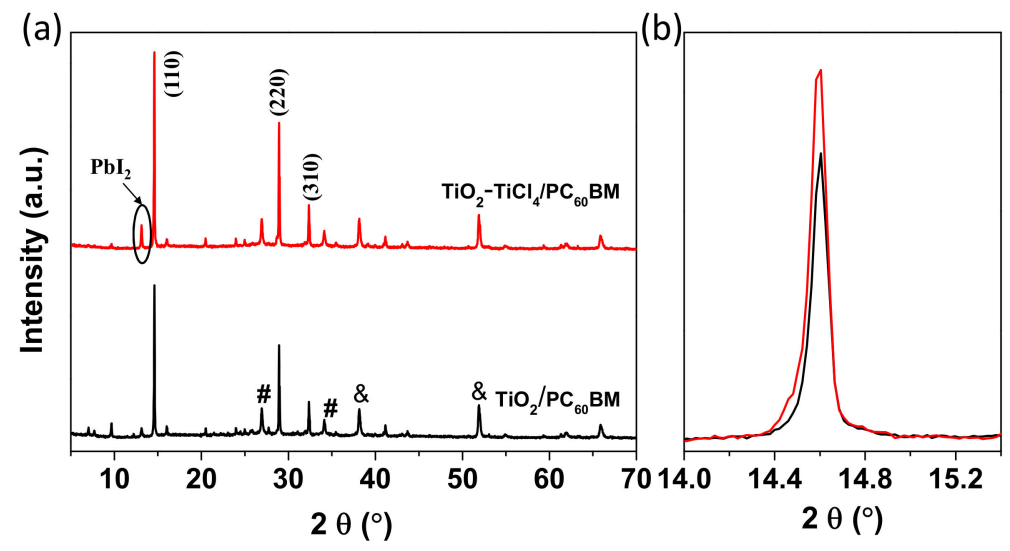

Figure 4. XRD patterns (a) and zoomed-in XRD patterns (b) of perovskite films deposited on $\mathrm{TiO}_{2}$ and $\mathrm{TiCl}_{4}$-treated $\mathrm{TiO}_{2}$ ETLs. "\#" and "\&" represent the characteristic peaks of fluorine-doped tin oxide (FTO) and $\mathrm{TiO}_{2}$, respectively.

The film absorption spectra of perovskite films deposited on $\mathrm{TiO}_{2}$ and $\mathrm{TiCl}_{4}$-treated ETLs were investigated by UV-Vis spectroscopy. Both films exhibited high absorption intensity over the entire UV-visible range, and the absorption band edge was around $1.61 \mathrm{eV}$ (Figure 5). Compared with pristine $\mathrm{TiO}_{2}$ ETL, the absorption of the perovskite film based on $\mathrm{TiCl}_{4}$-treated $\mathrm{TiO}_{2}$ ETL was significantly enhanced, indicating enhanced crystallinity of the resulting thin film.

To further investigate the photophysical properties of the thin films, steady-state photoluminescence (PL) and time-resolved PL (TR-PL) measurements of perovskite thin films were 
further investigated. The perovskite film based on $\mathrm{TiCl}_{4}$-treated $\mathrm{TiO}_{2}$ ETL showed larger PL intensity decay compared to the pristine $\mathrm{TiO}_{2}$-based perovskite film (Figure 6), indicating a faster charge transfer process between $\mathrm{TiO}_{2}$ and perovskite thin films [30]. Furthermore, the PL lifetimes of perovskite films on glass were also measured (Figure 7). By fitting the TR-PL curves with biexponential function, two decay parts — fast decay and slow decay — could be obtained [14]. The average lifetimes derived from the fitting curves were around 25.7 and 29.8 ns for perovskite films with and without $\mathrm{TiCl}_{4}$ treatment, respectively. The decreased PL lifetime is related to the efficient charge carrier transfer induced quenching process [27]. This is essential for efficient charge extraction and collection of the device.

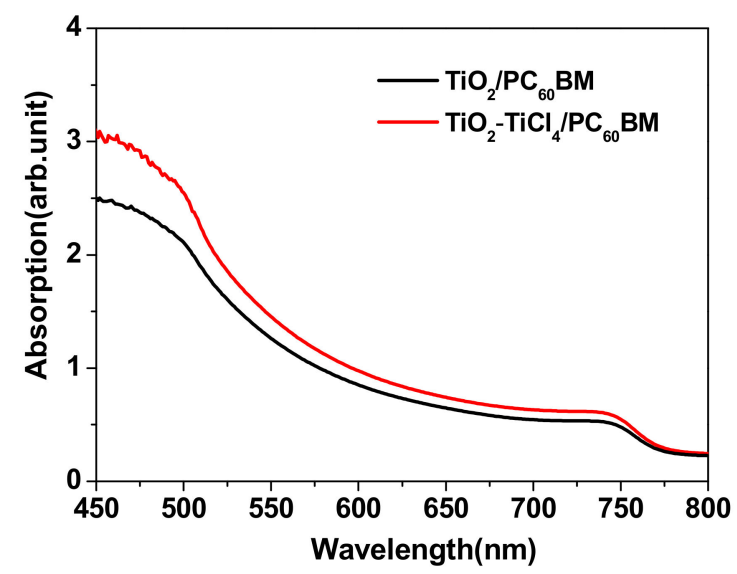

Figure 5. UV-vis spectra of perovskite films deposited on $\mathrm{TiO}_{2}$ and $\mathrm{TiCl}_{4}$-treated $\mathrm{TiO}_{2}$ ETLs.

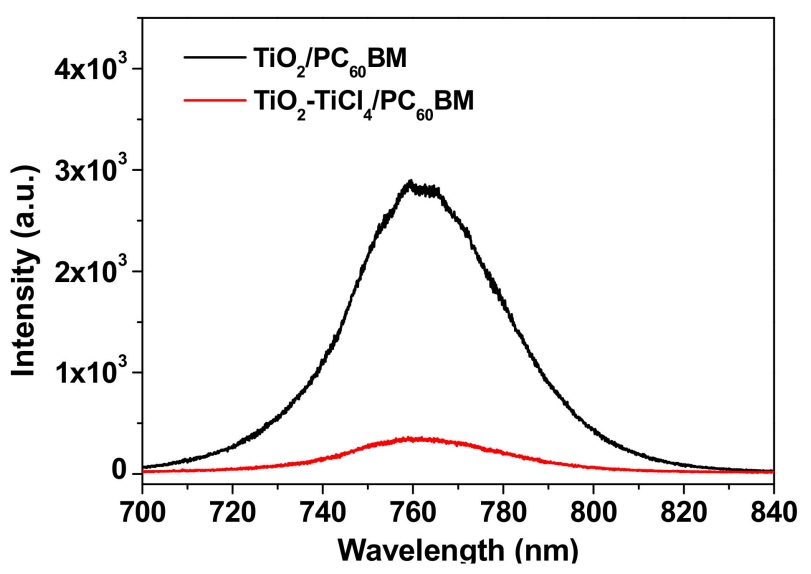

Figure 6. Photoluminescence (PL) spectra of perovskite films deposited on $\mathrm{TiO}_{2}$ and $\mathrm{TiCl}_{4}$-treated $\mathrm{TiO}_{2}$ ETLs.

The effect of $\mathrm{TiCl}_{4}$ treatment on PSC device performance was studied based on a planar structure with a configuration of $\mathrm{FTO} / \mathrm{TiO}_{2} / \mathrm{PC}_{60} \mathrm{BM} / \mathrm{CH}_{3} \mathrm{NH}_{3} \mathrm{PbI}_{3-x} \mathrm{Cl}_{x}$ /spiro-OMeTAD/Ag. Figure 8 exhibits the current density - voltage $(J-V)$ curves of PSC devices with and without $\mathrm{TiCl}_{4}$ treatment, and Table 1 summarizes the corresponding device parameters. In Figure 8, a PCE of $13.2 \%$ ( $V_{\text {oc }}$ of $1.04 \mathrm{~V}$, $J_{\mathrm{sc}}$ of $19.1 \mathrm{~mA} / \mathrm{cm}^{2}$, and FF of 0.66) can be seen for the device with pristine $\mathrm{TiO}_{2}$. By comparison, all the parameters, i.e., $V_{\mathrm{oc}}, J_{\mathrm{sc}}$, and $\mathrm{FF}$, for the device with $\mathrm{TiCl}_{4}$ treatment were enhanced simultaneously, resulting in an improved average PCE of $16.5 \%\left(V_{\mathrm{oc}}\right.$ of $1.08 \mathrm{~V}, J_{\mathrm{sc}}$ of $22.4 \mathrm{~mA} / \mathrm{cm}^{2}$, and FF of 0.68$)$. The device series resistance $\left(R_{\mathrm{S}}\right)$ and shunt resistance $\left(R_{\mathrm{sh}}\right)$ were also calculated to further understand the improvement in performance. Compared to the device without $\mathrm{TiCl}_{4}$ treatment, the $R_{\mathrm{s}}$ value of the device with $\mathrm{TiCl}_{4}$ treatment decreased to $3.7 \Omega \cdot \mathrm{cm}^{2}$, while the $R_{\mathrm{sh}}$ increased to $6.9 \mathrm{k} \Omega \cdot \mathrm{cm}$. The decreased $R_{\mathrm{s}}$ and increased $R_{\mathrm{sh}}$ are responsible for the $J_{\mathrm{sc}}$ and FF enhancement [7]. It needs to be 
mentioned that, when the high-temperature $\mathrm{TiO}_{2}$ was replaced with the low-temperature $\mathrm{ZnO}$ layer, the device also showed similar improvement. The $\mathrm{ZnO}$ with $\mathrm{TiCl}_{4}$ treatment revealed an improved PCE of $17.0 \%$ with a $V_{\mathrm{oc}}$ of $1.08 \mathrm{~V}, J_{\mathrm{sc}}$ of $23.2 \mathrm{~mA} / \mathrm{cm}^{2}$, and FF of 0.67 , which was much higher than those of the device with pristine $\mathrm{ZnO}$.

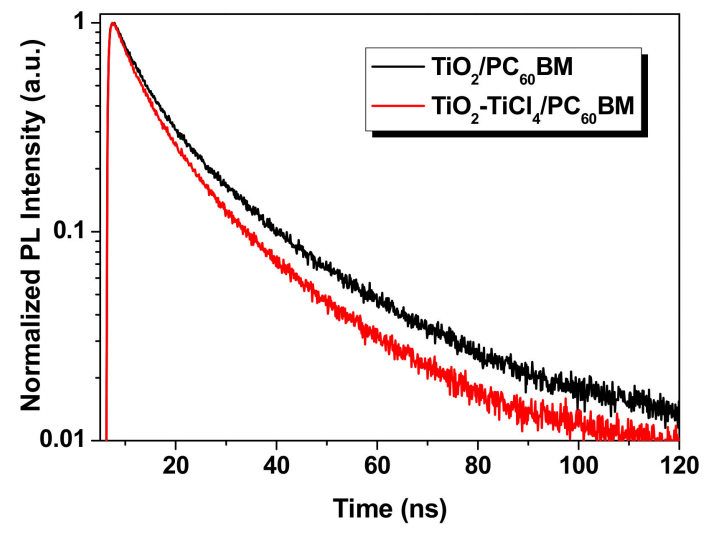

Figure 7. Time-resolved PL (TR-PL) spectra of perovskite films deposited on $\mathrm{TiO}_{2}$ and $\mathrm{TiCl}_{4}$-treated $\mathrm{TiO}_{2}$ ETLs.
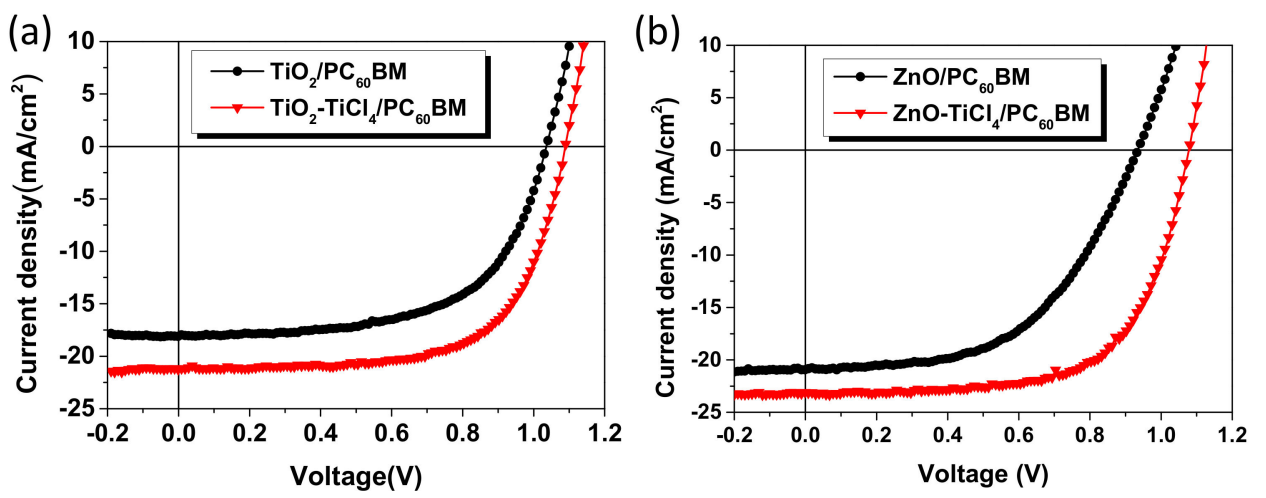

Figure 8. Current density - voltage $(J-V)$ characteristics of devices based on $\mathrm{TiO}_{2}(\mathbf{a})$ and $\mathrm{ZnO}(\mathbf{b})$ ETLs with and without $\mathrm{TiCl}_{4}$ treatment.

Table 1. Device parameters of perovskite solar cells (PSCs) with and without $\mathrm{TiCl}_{4}$ treatment.

\begin{tabular}{ccccccc}
\hline Interlayer & $\boldsymbol{V}_{\mathbf{o c}}(\mathbf{V})$ & $\left.\boldsymbol{J}_{\mathbf{s c}} \mathbf{( \mathbf { m A }} / \mathbf{c m}^{\mathbf{2}}\right)$ & $\mathbf{F F}$ & $\mathbf{P C E} \mathbf{( \% )}$ & $\boldsymbol{R}_{\mathbf{s}}\left(\boldsymbol{\Omega} \mathbf{~ c m}^{\mathbf{2}}\right)$ & $\boldsymbol{R}_{\mathbf{s h}}\left(\mathbf{k} \boldsymbol{\Omega} \mathbf{~ c m}^{\mathbf{2}}\right)$ \\
\hline $\mathrm{TiO}_{2} / \mathrm{PCBM}$ & 1.04 & 19.1 & 0.66 & 13.2 & 5.9 & 4.1 \\
$\mathrm{TiO}_{2}-\mathrm{TiCl}_{4} / \mathrm{PCBM}$ & 1.08 & 22.4 & 0.68 & 16.5 & 3.7 & 6.9 \\
$\mathrm{ZnO} / \mathrm{PCBM}$ & 0.93 & 20.7 & 0.53 & 10.2 & 10.2 & 1.5 \\
$\mathrm{ZnO}-\mathrm{TiCl}_{4} / \mathrm{PCBM}$ & 1.08 & 23.2 & 0.67 & 17.0 & 5.1 & 2.8 \\
\hline
\end{tabular}

The device hysteresis behavior is also a significant parameter to determine the final performance of the device. It can be affected by many factors, such as carrier trapping, ion motion, charge accumulation at interfaces, and so on [45-48]. The device hysteresis behaviors under different scan directions were measured (Figure 9). The device did not exhibit serious hysteresis behavior before and after $\mathrm{TiCl}_{4}$ treatment, indicating that $\mathrm{TiCl}_{4}$ has less effect than PCBM, which plays a major role in determining the final hysteresis behavior.

In order to further investigate the mechanism involved in performance enhancement, transient photocurrent and photovoltage measurements of perovskite solar cells were performed. Figure 10a shows the transient photocurrent decay of perovskite devices measured at short-circuit condition. After $\mathrm{TiCl}_{4}$ treatment, the devices exhibited faster decay with shorter lifetime $(1.02 \mu \mathrm{s})$ compared to 
the pristine $\mathrm{TiO}_{2}$-based device $(1.78 \mu \mathrm{s})$. This indicates that the device with $\mathrm{TiCl}_{4}$ treatment possessed more efficient charge transfer process. The transient photovoltage was used to determine the charge recombination process (Figure 10b). It can be clearly seen that the device with $\mathrm{TiCl}_{4}$ treatment exhibited much longer lifetime $(2.32 \mathrm{~ms})$ compared to the pristine $\mathrm{TiO}_{2}$-based device $(1.66 \mathrm{~ms})$. This indicates that the charge recombination process was efficiently suppressed. Hence, the $J_{\mathrm{sc}}$ and FF exhibited significant improvement.
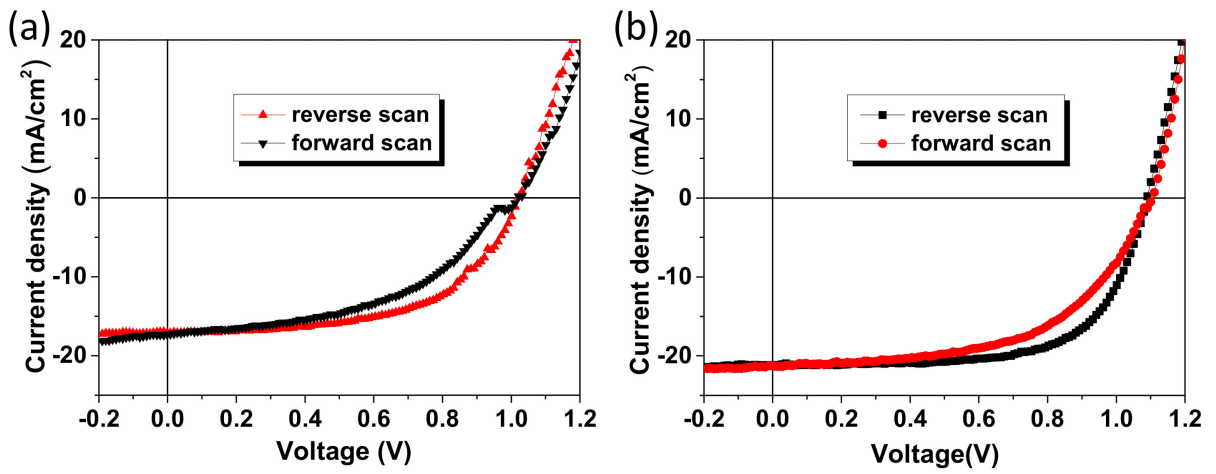

Figure 9. Hysteresis behavior of devices based on $\mathrm{TiO}_{2}$ ETL without (a) and with (b) $\mathrm{TiCl}_{4}$ treatment.
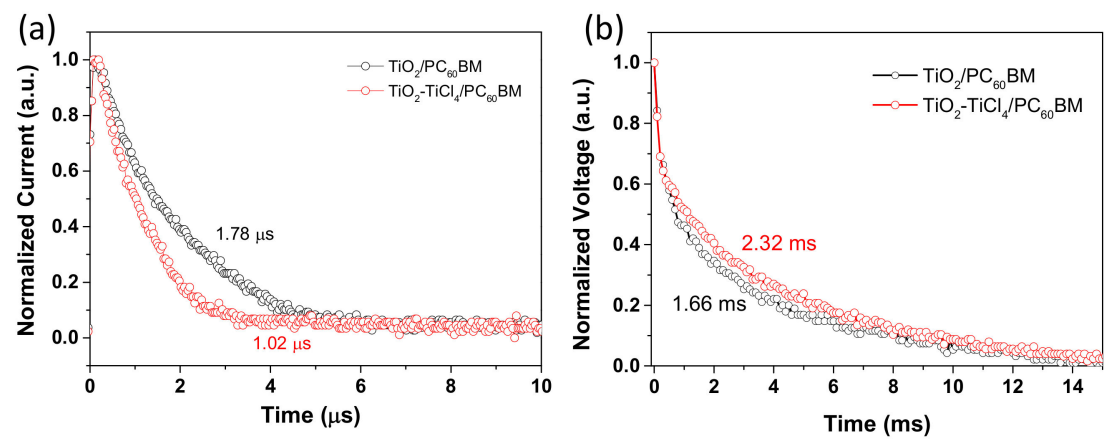

Figure 10. (a) Transient photocurrent and (b) photovoltage decay characteristics of perovskite solar cells based on $\mathrm{TiO}_{2}$ ETL with and without $\mathrm{TiCl}_{4}$ treatment.

\section{Conclusions}

In conclusion, we investigated the effect of $\mathrm{TiCl}_{4}$ treatment on perovskite thin film formation and PSC device performance. The results showed that $\mathrm{TiCl}_{4}$ treatment had a beneficial effect on the properties of perovskite thin film. It could enhance thin film crystallinity and improve charge transfer and extraction. Finally, the PCE was enhanced from $13.2 \%$ to $16.5 \%$ for devices based on $\mathrm{TiO}_{2}$ ETL and from $10.2 \%$ to $17.0 \%$ for devices based on ZnO ETL. This is important for understanding interfacial treatment and further improves device efficiency and stability.

Author Contributions: Conceptualization, Z.L.; methodology, G.L., X.W. and J.D.; validation, J.M.; formal analysis, G.L., M.Z. and J.M.; investigation, G.L., J.D. and Y.G.; resources, X.W., M.Z., and Y.L.; data curation, G.L., X.W. and J.M.; writing — original draft preparation, G.L.; writing—review and editing, Z.L., G.L. and J.M.; visualization, J.D., M.Z., Y.G. and Y.L.; supervision, Z.L.; project administration, Z.L. All authors have read and agreed to the published version of the manuscript.

Funding: This research was funded by National Natural Science Foundation of China, grant number 61604119, 61704131, and 61804111, and the Fundamental Research Funds for the Central Universities.

Conflicts of Interest: The authors declare no conflict of interest. 


\section{References}

1. Chen, W.; Wu, Y.; Yue, Y.; Liu, J.; Zhang, W.; Yang, X.; Chen, H.; Bi, E.; Ashraful, I.; Grätzel, M.; et al. Efficient and stable large-area perovskite solar cells with inorganic charge extraction layers. Science 2015, 350, 944-948. [CrossRef] [PubMed]

2. Xing, G.; Mathews, N.; Sun, S.; Lim, S.S.; Lam, Y.M.; Grätzel, M.; Mhaisalkar, S.; Sum, T.C. Long-range balanced electron- and hole-transport lengths in organic-inorganic CH3NH3PbI3. Science 2013, 342, 344-347. [CrossRef] [PubMed]

3. Shi, D.; Adinolfi, V.; Comin, R.; Yuan, M.; Alarousu, E.; Buin, A.; Chen, Y.; Hoogland, S.; Rothenberger, A.; Katsiev, K.; et al. Low trap-state density and long carrier diffusion in organolead trihalide perovskite single crystals. Science 2015, 347, 519-522. [CrossRef] [PubMed]

4. Dong, Q.; Fang, Y.; Shao, Y.; Mulligan, P.; Qiu, J.; Cao, L.; Huang, J. Electron-hole diffusion lengths $>175 \mu \mathrm{m}$ in solution-grown $\mathrm{CH}_{3} \mathrm{NH}_{3} \mathrm{PbI}_{3}$ single crystals. Science 2015, 347, 967-970. [CrossRef] [PubMed]

5. Stranks, S.D.; Eperon, G.E.; Grancini, G.; Menelaou, C.; Alcocer, M.J.P.; Leijtens, T.; Herz, L.M.; Petrozza, A.; Snaith, H.J. Electron-Hole Diffusion Lengths Exceeding 1 Micrometer in an Organometal Trihalide Perovskite Absorber. Science 2013, 342, 341-344. [CrossRef] [PubMed]

6. Lee, M.M.; Teuscher, J.; Miyasaka, T.; Murakami, T.N.; Snaith, H.J. Efficient Hybrid Solar Cells Based on Meso-Superstructured Organometal Halide Perovskites. Science 2012, 338, 643-647. [CrossRef]

7. Yang, W.S.; Park, B.-W.; Jung, E.H.; Jeon, N.J.; Kim, Y.C.; Lee, D.U.; Shin, S.S.; Seo, J.; Kim, E.K.; Noh, J.H.; et al. Iodide management in formamidinium-lead-halide-based perovskite layers for efficient solar cells. Science 2017, 356, 1376-1379. [CrossRef]

8. Chang, J.; Zhu, H.; Li, B.; Isikgor, F.H.; Hao, Y.; Xu, Q.; Ouyang, J. Boosting the performance of planar heterojunction perovskite solar cell by controlling the precursor purity of perovskite materials. J. Mater. Chem. A 2016, 4, 887-893. [CrossRef]

9. Chang, J.; Zhu, H.; Xiao, J.; Isikgor, F.H.; Lin, Z.; Hao, Y.; Zeng, K.; Xu, Q.-H.; Ouyang, J. Enhancing the planar heterojunction perovskite solar cell performance through tuning the precursor ratio. J. Mater. Chem. A 2016, 4, 7943-7949. [CrossRef]

10. Ma, J.; Su, J.; Lin, Z.; Zhou, L.; He, J.; Zhang, J.; Liu, S.; Chang, J.; Hao, Y. Improve the oxide/perovskite heterojunction contact for low temperature high efficiency and stable all-inorganic CsPbI2Br perovskite solar cells. Nano Energy 2019, 104241. [CrossRef]

11. Mo, J.; Zhang, C.; Chang, J.; Yang, H.; Xi, H.; Chen, D.; Lin, Z.; Lu, G.; Zhang, J.; Hao, Y. Enhanced efficiency of planar perovskite solar cells via a two-step deposition using DMF as an additive to optimize the crystal growth behavior. J. Mater. Chem. A 2017, 5, 13032-13038. [CrossRef]

12. Chang, J.; Lin, Z.; Zhu, H.; Isikgor, F.H.; Xu, Q.-H.; Zhang, C.; Hao, Y.; Ouyang, J. Enhancing the photovoltaic performance of planar heterojunction perovskite solar cells by doping the perovskite layer with alkali metal ions. J. Mater. Chem. A 2016, 4, 16546-16552. [CrossRef]

13. Jeon, N.J.; Noh, J.H.; Yang, W.S.; Kim, Y.C.; Ryu, S.; Seo, J.; Seok, S. I Compositional engineering of perovskite materials for high-performance solar cells. Nature 2015, 517, 476-480. [CrossRef] [PubMed]

14. Liu, Z.; Chang, J.; Lin, Z.; Zhou, L.; Yang, Z.; Chen, D.; Zhang, C.; Liu, S.F.; Hao, Y. High-Performance Planar Perovskite Solar Cells Using Low Temperature, Solution-Combustion-Based Nickel Oxide Hole Transporting Layer with Efficiency Exceeding 20\%. Adv. Energy Mater. 2018, 8, 1703432. [CrossRef]

15. Zhou, L.; Chang, J.; Liu, Z.; Sun, X.; Lin, Z.; Chen, D.; Zhang, C.; Zhang, J.; Hao, Y. Enhanced planar perovskite solar cell efficiency and stability using a perovskite/PCBM heterojunction formed in one step. Nanoscale 2018, 10, 3053-3059. [CrossRef] [PubMed]

16. Zhou, L.; Lin, Z.; Ning, Z.; Li, T.; Guo, X.; Ma, J.; Su, J.; Zhang, C.; Zhang, J.; Liu, S.; et al. Highly Efficient and Stable Planar Perovskite Solar Cells with Modulated Diffusion Passivation Toward High Power Conversion Efficiency and Ultrahigh Fill Factor. Sol. RRL 2019, 1900293. [CrossRef]

17. Wang, S.; Zhang, B.; Feng, D.; Lin, Z.; Zhang, J.; Hao, Y.; Fan, X.; Chang, J. Achieving high performance and stable inverted planar perovskite solar cells using lithium and cobalt co-doped nickel oxide as hole transport layers. J. Mater. Chem. C 2019, 7, 9270-9277. [CrossRef]

18. Zhang, Z.; Su, J.; Hou, J.; Lin, Z.; Hu, Z.; Chang, J.; Zhang, J.; Hao, Y. Potential Applications of Halide Double Perovskite Cs 2 AgInX $6(\mathrm{X}=\mathrm{Cl}, \mathrm{Br})$ in Flexible Optoelectronics: Unusual Effects of Uniaxial Strains. J. Phys. Chem. Lett. 2019, 10, 1120-1125. [CrossRef] 
19. Lin, Z.; Chang, J.; Xiao, J.; Zhu, H.; Xu, Q.-H.; Zhang, C.; Ouyang, J.; Hao, Y. Interface studies of the planar heterojunction perovskite solar cells. Sol. Energy Mater. Sol. Cells 2016, 157, 783-790. [CrossRef]

20. Chueh, C.-C.; Li, C.-Z.; Jen, A.K.-Y. Recent progress and perspective in solution-processed Interfacial materials for efficient and stable polymer and organometal perovskite solar cells. Energy Environ. Sci. 2015, 8, 1160-1189. [CrossRef]

21. Ma, J.; Chang, J.; Lin, Z.; Guo, X.; Zhou, L.; Liu, Z.; Xi, H.; Chen, D.; Zhang, C.; Hao, Y. Elucidating the Roles of TiCl 4 and PCBM Fullerene Treatment on TiO 2 Electron Transporting Layer for Highly Efficient Planar Perovskite Solar Cells. J. Phys. Chem. C 2018, 122, 1044-1053. [CrossRef]

22. Zhou, Z.; Pang, S.; Liu, Z.; Xu, H.; Cui, G. Interface Engineering for High-Performance Perovskite Hybrid Solar Cells. J. Mater. Chem. A 2015, 3, 19205-19217. [CrossRef]

23. Fu, F.; Feurer, T.; Jäger, T.; Avancini, E.; Bissig, B.; Yoon, S.; Buecheler, S.; Tiwari, A.N. Low-temperature-processed efficient semi-transparent planar perovskite solar cells for bifacial and tandem applications. Nat. Commun. 2015, 6, 8932. [CrossRef] [PubMed]

24. Correa Baena, J.P.; Steier, L.; Tress, W.; Saliba, M.; Neutzner, S.; Matsui, T.; Giordano, F.; Jacobsson, T.J.; Srimath Kandada, A.R.; Zakeeruddin, S.M.; et al. Highly efficient planar perovskite solar cells through band alignment engineering. Energy Environ. Sci. 2015, 8, 2928-2934. [CrossRef]

25. Ke, W.; Fang, G.; Liu, Q.; Xiong, L.; Qin, P.; Tao, H.; Wang, J.; Lei, H.; Li, B.; Wan, J.; et al. Low-Temperature Solution-Processed Tin Oxide as an Alternative Electron Transporting Layer for Efficient Perovskite Solar Cells. J. Am. Chem. Soc. 2015, 137, 6730-6733. [CrossRef]

26. Li, Y.; Zhao, Y.; Chen, Q.; Yang, Y.; Liu, Y.; Hong, Z.; Liu, Z.; Hsieh, Y.T.; Meng, L.; Li, Y.; et al. Multifunctional Fullerene Derivative for Interface Engineering in Perovskite Solar Cells. J. Am. Chem. Soc. 2015, 137, 15540-15547. [CrossRef]

27. Ma, J.; Guo, X.; Zhou, L.; Lin, Z.; Zhang, C.; Yang, Z.; Lu, G.; Chang, J.; Hao, Y. Enhanced Planar Perovskite Solar Cell Performance via Contact Passivation of $\mathrm{TiO}_{2} /$ Perovskite Interface with $\mathrm{NaCl}$ Doping Approach. ACS Appl. Energy Mater. 2018, 1, 3826-3834. [CrossRef]

28. Pascual, J.; Kosta, I.; Tuyen Ngo, T.; Chuvilin, A.; Cabanero, G.; Grande, H.J.; Barea, E.M.; Mora-Seró, I.; Delgado, J.L.; Tena-Zaera, R. Electron Transport Layer-Free Solar Cells Based on Perovskite-Fullerene Blend Films with Enhanced Performance and Stability. ChemSusChem 2016, 9, 2679-2685. [CrossRef]

29. Sandoval-Torrientes, R.; Pascual, J.; García-Benito, I.; Collavini, S.; Kosta, I.; Tena-Zaera, R.; Martín, N.; Delgado, J.L. Modified Fullerenes for Efficient Electron Transport Layer-Free Perovskite/Fullerene Blend-Based Solar Cells. ChemSusChem 2017, 10, 2023-2029. [CrossRef]

30. Ma, J.; Lin, Z.; Guo, X.; Zhou, L.; Su, J.; Zhang, C.; Yang, Z.; Chang, J.; Liu, S.; Hao, Y. Low-Temperature Solution-Processed ZnO Electron Transport Layer for Highly Efficient and Stable Planar Perovskite Solar Cells with Efficiency Over 20\%. Sol. RRL 2019, 3, 1900096. [CrossRef]

31. You, J.; Meng, L.; Song, T.-B.; Guo, T.-F.; Yang, Y.; Chang, W.-H.; Hong, Z.; Chen, H.; Zhou, H.; Chen, Q.; et al. Improved air stability of perovskite solar cells via solution-processed metal oxide transport layers. Nat. Nanotechnol. 2015, 11, 75-81. [CrossRef] [PubMed]

32. Zhao, P.; Lin, Z.; Wang, J.; Yue, M.; Su, J.; Zhang, J.; Chang, J.; Hao, Y. Numerical Simulation of Planar Heterojunction Perovskite Solar Cells Based on SnO2 Electron Transport Layer. ACS Appl. Energy Mater. 2019, 2, 4504-4512. [CrossRef]

33. Zhang, S.; Su, J.; Lin, Z.; Tian, K.; Guo, X.; Zhang, J.; Chang, J.; Hao, Y. Beneficial Role of Organolead Halide Perovskite $\mathrm{CH}_{3} \mathrm{NH}_{3} \mathrm{PbI}_{3} / \mathrm{SnO}_{2}$ Interface: Theoretical and Experimental Study. Adv. Mater. Interfaces 2019, 6, 1900400. [CrossRef]

34. Guo, X.; Lin, Z.; Ma, J.; Hu, Z.; Su, J.; Zhang, C.; Zhang, J.; Chang, J.; Hao, Y. Low temperature combustion synthesized indium oxide electron transport layer for high performance and stable perovskite solar cells. J. Power Sources 2019, 438, 226981. [CrossRef]

35. Zhou, L.; Guo, X.; Lin, Z.; Ma, J.; Su, J.; Hu, Z.; Zhang, C.; Liu, S.; Chang, J.; Hao, Y. Interface engineering of low temperature processed all-inorganic CsPbI2Br perovskite solar cells toward PCE exceeding $14 \%$. Nano Energy 2019, 60, 583-590. [CrossRef]

36. Zhao, P.; Feng, L.; Lin, Z.; Wang, J.; Su, J.; Hu, Z.; Zhang, J.; Ouyang, X.; Chang, J.; Hao, Y. Theoretical Analysis of Two-Terminal and Four-Terminal Perovskite/CIGS Tandem Solar Cells. Sol. RRL 2019, 1900303. [CrossRef] 
37. Guo, X.; Zhang, B.; Lin, Z.; Su, J.; Yang, Z.; Zhang, C.; Chang, J.; Liu, S.; Hao, Y. Highly efficient perovskite solar cells based on a dopant-free conjugated DPP polymer hole transport layer: Influence of solvent vapor annealing. Sustain. Energy Fuels 2018, 2, 2154-2159. [CrossRef]

38. Peng, J.; Wu, Y.; Ye, W.; Jacobs, D.A.; Shen, H.; Fu, X.; Wan, Y.; Duong, T.; Wu, N.; Barugkin, C.; et al. Interface passivation using ultrathin polymer-fullerene films for high-efficiency perovskite solar cells with negligible hysteresis. Energy Environ. Sci. 2017, 10, 1792-1800. [CrossRef]

39. Liu, Z.; Chen, Q.; Hong, Z.; Zhou, H.; Xu, X.; De Marco, N.; Sun, P.; Zhao, Z.; Cheng, Y.B.; Yang, Y. Low-Temperature TiOx Compact Layer for Planar Heterojunction Perovskite Solar Cells. ACS Appl. Mater. Interfaces 2016, 8, 11076-11083. [CrossRef]

40. Collavini, S.; Kosta, I.; Völker, S.F.; Cabanero, G.; Grande, H.J.; Tena-Zaera, R.; Delgado, J.L. Efficient Regular Perovskite Solar Cells Based on Pristine [70]Fullerene as Electron-Selective Contact. ChemSusChem 2016, 9, 1263-1270. [CrossRef]

41. Wojciechowski, K.; Stranks, S.D.; Abate, A.; Sadoughi, G.; Sadhanala, A.; Kopidakis, N.; Rumbles, G.; Li, C.-Z.; Friend, R.H.; Jen, A.K.-Y.; et al. Heterojunction Modification for Highly Efficient Organic-Inorganic Perovskite Solar Cells. ACS Nano 2014, 8, 12701-12709. [CrossRef] [PubMed]

42. Abdi-Jalebi, M.; Dar, M.I.; Sadhanala, A.; Senanayak, S.P.; Giordano, F.; Zakeeruddin, S.M.; Grätzel, M.; Friend, R.H. Impact of a Mesoporous Titania-Perovskite Interface on the Performance of Hybrid Organic-Inorganic Perovskite Solar Cells. J. Phys. Chem. Lett. 2016, 7, 3264-3269. [CrossRef] [PubMed]

43. Choe, G.; Kang, J.; Ryu, I.; Song, S.W.; Kim, H.M.; Yim, S. Influence of the concentration of $\mathrm{TiCl}_{4}$ solution used for post-treatment on mesoporous $\mathrm{TiO}_{2}$ layers in hybrid lead halide perovskite solar cells. Sol. Energy 2017, 155, 1148-1156. [CrossRef]

44. Murakami, T.N.; Miyadera, T.; Funaki, T.; Cojocaru, L.; Kazaoui, S.; Chikamatsu, M.; Segawa, H. Adjustment of Conduction Band Edge of Compact $\mathrm{TiO}_{2}$ Layer in Perovskite Solar Cells Through $\mathrm{TiCl}_{4}$ Treatment. ACS Appl. Mater. Interfaces 2017, 9, 36708-36714. [CrossRef] [PubMed]

45. Chen, H.; Sakai, N.; Ikegami, M.; Miyasaka, T. Emergence of Hysteresis and Transient Ferroelectric Response in Organo-Lead Halide Perovskite Solar Cells. J. Phys. Chem. Lett. 2015, 6, 164-169. [CrossRef] [PubMed]

46. Meloni, S.; Moehl, T.; Tress, W.; Franckevičius, M.; Saliba, M.; Lee, Y.H.; Gao, P.; Nazeeruddin, M.K.; Zakeeruddin, S.M.; Rothlisberger, U.; et al. Ionic polarization-induced current-voltage hysteresis in CH3NH3PbX3 perovskite solar cells. Nat. Commun. 2016, 7, 10334. [CrossRef]

47. Almora, O.; Aranda, C.; Zarazua, I.; Guerrero, A.; Garcia-Belmonte, G. Noncapacitive Hysteresis in Perovskite Solar Cells at Room Temperature. ACS Energy Lett. 2016, 1, 209-215. [CrossRef]

48. Zhao, C.; Chen, B.; Qiao, X.; Luan, L.; Lu, K.; Hu, B. Revealing Underlying Processes Involved in Light Soaking Effects and Hysteresis Phenomena in Perovskite Solar Cells. Adv. Energy Mater. 2015, 5, 1500279. [CrossRef]

(C) 2020 by the authors. Licensee MDPI, Basel, Switzerland. This article is an open access article distributed under the terms and conditions of the Creative Commons Attribution (CC BY) license (http://creativecommons.org/licenses/by/4.0/). 